Отримано: 12 вересня 2021 p.

Прорецензовано: 29 жовтня 2021 р.

Прийнято до друку: 1 грудня 2021 р.

e-mail: storchak.oleg@gmail.com

DOI: $10.25264 / 2519-2558-2021-12(80)-10-14$
Storchak O. H. Strategies of conveying English anthroponyms in Ukrainian. Наукові записки Національного університету «Острозька академія»: серія «Філологія». Острог : Вид-во НаУОА, 2021. Вип. 12(80). С. 10-14.

Oleg Storchak,
PhD in Philology, Associate Professor of Foreign Languages Department,

Kharkiv National University of Radioelectronics

\title{
STRATEGIES OF CONVEYING ENGLISH ANTHROPONYMS IN UKRAINIAN
}

The rendering of personal names from English into Ukrainian is complex activity with rigid rules. Personal names have six main functions: identification, reference, individualisation, differentiation, classification and categorisation. The proper names of people can signal gender, race, social class, age and nationality. Personal names have impoverished semantics and no reliable information can be gained from them. The names rendered improperly may bias or obscure reality. The signalling power of an English personal name in Ukrainian graphics is lower than that of the name in English graphics. The methods of rendering proper names are semantic translation, functional analogue, transliteration, transcription, transposition, tradition, tracing, half-tracing, euphonic rendering, explication, combined rendering, rendering a name in Latin without changes and transplantation. The strategies to render English anthroponyms into Ukrainian are based on these methods, the semantics of a name, its image and function, national and language specifics, a pragmatic task and the use of a dictionary. To convey people's proper names in Ukrainian, it is necessary to make sure that the word calls a person, to identify the national and language origin of the name, to determine traditional variants and choose appropriate strategies. The personal name rendered becomes part of Ukrainian text.

Key words: personal name, proper name, anthroponym, semantics, rendering, strategy, method, English graphics, Ukrainian graphics.

Сторчак Олег Григорович,

кандидат філологічних наук, доцент кафедри іноземних мов,

Харківський національний університет радіоелектроніки

\section{СТРАТЕГІЇ ПЕРЕДАЧІ АНГЛІЙСЬКИХ АНТРОПОНІМІВ ГРАФІЧНИМИ ЗАСОБАМИ УКРАЇНСЬКОЇ МОВИ}

У иьому дослідженні проведено наукову розвідку стратегій передачі англійських власних імен людей засобами української мови. Власні імена виконують шість основних функцій: ідентифікацію, посилання, індивідуалізачію, диференціацію, класифікаиію і категоризаиію. Власні імена людей, хоча й мають збіднілу семантику, можуть містити інформаиію про гендерну, расову і національну приналежність, соиіальний клас і вік. Методами передачі власних імен є семантичний переклад, функиіональний аналог, транслітерація, транскрипиія, транспозиція, традиційність, калькування, напівкалькування, евфонічна передача, експлікачія, комбінована передача, передача імені латиницею без змін і трансплантація. Стратегії передачі англійських антропонімів українською мовою базуються на иих методах, семантииі імені, його образі й функції, національно-мовній специффіџі, прагматичній задачі та використанні словника. Перекладене на українську мову власне ім'я стає частиною украӥнського тексту. Англійське власне ім'я, передане засобами української графіки, несе менше семантичне навантаження, ніж те ж саме ім'я, відображене засобами англійської графіки.

Ключові слова: власне ім'я, антропонім, семантика, передача, стратегія, метод, англійська графіка, українська графіка.

The conveying of English surnames and first names (the Latin alphabet) in the Ukrainian language (the Cyrillic alphabet) is a complex pragmatic task that involves knowledge of culture, history, languages and cognitive capacities. The scientific task is to provide theoretical and practical tools for correct rendering English proper names into the Ukrainian language.

The aim of the research is to provide the strategies to convey English proper names of people in the Ukrainian language in order that the perception of a personal name in Ukrainian text can be similar to its perception in English.

Oxford Advanced Learner's Dictionary (2015) defines a proper noun as "a word that is the name of a person, a place, an institution, etc. and is written with a capital letter" [19, p. 1233]. International Council of Onomastic Sciences provides classification of proper names that are divided into 19 groups; six of them are related to people, namely, anthroponym, hypocoristic, metronym, patronym, teknonym and theonym. Another classification divides names of people into family names, first names, pseudonyms and nicknames $[20$, p. 3$]$.

The object of the research is the strategies of conveying English anthroponyms in Ukrainian. The subject of the research is English and Ukrainian antroponyms. The research is of topical interest as it concerns the exactitude of rendering English proper names into Ukrainian. Research materials are scientific and educational materials.

The methodology of the research is based on an onomastics oriented standpoint. Onomastics is the study of the history and origin of names, especially names of people. The methods of the research are etymological, semasiological, component, cognitive, conceptual and contextual analyses. General scientific methods of the research are analysis, synthesis and comparison.

Proper names are studied in Linguistics, Cognitive Psychology, Philosophy and other sciences in terms of their functions, meanings, connotations, identity, cognitive resources, memory for names as well as lingual and extralingual factors that can have an impact on rendering proper names into foreign languages.

In Linguistics, proper names are investigated by D. Ermolovich, A. Rybakin, O. Superanska, R. D. Alford, W. H. Goodenough, N. C. Dorian, G. Cohen, Joseph Kasof, E. D. Lawson, Lynn M. Roeder just to name a few. A cross-cultural study of personal naming practice enables R. Alford to determine two functions of personal names: categorisation and differentiation [6]. Classification by W. Goodenough differentiates classificatory and individualising properties of names [12]. Individualising and classifying functions of personal names are emphasized by N. Dorian [10]. Garcia-Ramirez specifies a reference function of proper names [11, p. 164]. 
According to G. Vittmann, the personal name of an individual in Egypt was the most important means of identification in this life and in social memory for eternity [13]. So, the functions of personal names are categorization, differentiation, classification, individualization, reference and identification.

In Cognitive Psychology and Philosophy proper names are investigated by Tim Valentine, Tim Brennen, Serge Bredart, GarciaRamirez etc. [20]. Cognitive psychology views proper names of people as words with "impoverished semantics" that are not wellintegrated semantically [7]. The processes of meaning transfer and the relationship between a name and its referent are engendered several months after birth as children start learning proper names at the age of 4.5-6 months and common names at 9-10 months. Therefore, proper names demand minimal cognitive resources and have minimal content [11, p. 2, 8, 164].

Conveying personal names in foreign languages is a practical task. The transliteration of Ukrainian names by means of the English alphabet is standardized by the Regulations that are issued by the Cabinet of Ministers of Ukraine of 27 January 2010 № 55. The transliteration of English names by means of the Ukrainian alphabet is standardized by the Recommendations of the former State Service of Intellectual Property of the Ministry of Education and Science of Ukraine of 25 April 2001 and by other documents. In China in 1958, the Chinese phonetic alphabet was introduced to provide an alphaphonetic standard that can be used to transcribe foreign surnames and first names [1, c. 1].

The conveying of names is based on lingual and extralingual factors: pragmatic task; phonetic image of a person's proper name; connotations of a person's proper name; grammar articles with proper names; meaning; direct and nondirect equivalents.

A pragmatic task deals with the true content of a discourse. In legal texts, the conveying of proper names in a foreign language should be focused on legal requirements for names. In texts for children, perception and pronunciation of name can prevail. In scholarly texts, names can be transliterated on the basis of scientific consensus to satisfy special requirements.

The phonetic image of a personal name is formed on the basis of its etymology. If a language community has people whose names keep features of foreign languages, for example, people of German nationality in Ukraine, we can use German orthography to convey their proper names in Cyrillic [3, c. 21-23]. Peter Mark Roget, the author of Thesaurus of English Words and Phrases, lived in England but his name Roget is of French origin. So, the phonetic image of Roget is as in France rather than in England, i. e. Roget ['rozer] - Poжe in Ukrainian. When rendering the names of British citizens of non-English origin into Ukrainian, we should take into account original language spelling and pronunciation.

The connotations of names have been researched by Kasof (1993), Lawson and Roeder (1986), Mehrabian (1997), Sasha Shen Johfre (2020) and others. The connotations of people's names are derived from our lifelong experience of dealing with names. In some languages we can determine the gender of the bearer of a first name. There are exceptions, for instance, Leslie and Kim are of indeterminate gender in English-speaking countries [7, p. 142]. A name can be a clue to person's nationality and a social class. For instance, the names Lee and Waine, according to Tim Brennen, call up lower class images in England. There are the highestclass-sounding names (Hannah, Meredith, Madeline, Connor and Elizabeth) and the lowest-class-sounding names (Ciera, Tremayne, Precious, Perlie, and Terell). Names can carry connotations of age. Perception of age happens within milliseconds of interacting with a new person [8]. However, when using people's names without any visual image, the age of a person is perceived on the basis of the name only [14, p. 369]. According to Sasha Shen Johfre, the name of Deloris is perceived as the name of a woman of advanced age whereas Cayden is perceived as that of a young female [14, p. 373]. Last names weakly signal age, whereas first names signal age more effectively [14, p. 385]. Some names signal whiteness (e.g., Hunter, Emily, Heidi, Dick and Jill) and blackness (e.g., DeAndre, DaQuan, Keyshawn, Devonte and Lakisha). Several names are perceived as having equal likelihoods of being black and white (Ciera, Purlie, Brandi and Elijah) [14, p. 376]. Some androgynous names are perceived as relatively young. So, names can signal gender, nationality, social class, age and race. These connotations are weak and probabilistic though the impact of the connotative meanings of names is obvious.

In English, first and middle names and surnames usually have no article. If the definite or indefinite article is used with personal names, it adds semantics to personal names. 'The Dicksons' is rendered as сім'я Діксонів or Діксони, 'the Browns' as сім'я Браунів or Брауни. 'A David' can be translated as якийсь Девід; 'a Rembrandt' can mean a picture of Rembrandt. The definite article may be used with some nicknames, for instance, the Monster. In direct address, the article with a nickname is omitted, as a rule. Titles usually precede a personal name and are part of the name. Titles are capitalized and used without any article. So, semantics of names can vary depending on the article.

The meaning of people's proper names is widely illuminated in scholarly literature. Some researchers believe that proper names are meaningless [9] and are not processed for meaning [17]. Other researchers state that personal names are meaningful [15; 16; 18]. The third approach reads that a personal name is processed for meaning during the first few encounters with a person while the following encounters do not contribute to the processing of the name for meaning [7, p. 145]. So, personal names can be meaningless, meaningful or gradually lose their meaning for a partner.

English and Ukrainian graphics differ. In Latin, the apostrophe and the letter " $b$ " are absent. The phonetic system of English has direct equivalents in Ukrainian for some phonemes, for instance, $\mathrm{k}-\kappa, \mathrm{g}-\tau, \mathrm{z}-3, \mathrm{r}-p$. Some Ukrainian phonemes have no direct equivalents in English, for instance, the Ukrainian sound [г] is presented in English by the phoneme [h] (Гаврило - Наvrylo; Huxley - Гакслі); the Ukrainian phoneme [ж] - [zh] in English; the Ukrainian sound [щ] - [shch] in English; the Ukrainian sound $[\mathrm{x}]-[\mathrm{kh}]$ in English; palatalised sound [дз $\left.{ }^{\prime}\right]-[\mathrm{dz}]$ in English. English long vowel phonemes are substituted with short vowel phonemes in Ukrainian:

[a:] with [a]: Bart - Барm, Mark - Марк;

[э:] with [o]: Austin - Остін, Allcorn - Олкорн;

[u:] with [y]: Cooper-Kynep;

[ə:] with [e]: Herbert - Герберт etc.

The factors mentioned above have an impact on the choice of the methods to render English names into Ukrainian. The methods of rendering people's names into Ukrainian are as follows: semantic translation, functional analogue, transliteration, transliteration with omission or addition of a letter or two in Ukrainian, transcription, practical transcription, transposition, tradition, tracing, halftracing, euphonic rendering, explication, combined rendering, transplantation and personal name in Latin with no changes. 
The method of semantic translation is applied when we deal with nicknames of people: King Charles the Great - король Карл Великий, King Richard the Lionheart - король Річард Левине Серие, where the words Great and Lionheart are nicknames. Nicknames are conveyed irrespective of their origin: King Edward the Confessor - король Едуард Сповідник, Prince William of Orange - прини Вільгельм Оранський. In belles-lettres works, characterising names can be translated semantically: Guido the Gimlet - Гвідо Свердлик, Carlo the Corkscrew - Карло Штопор, Beowulf the Bradawl - Беовульф Шило in Guido the Gimlet of Ghent by Stephen Leacock. These are examples of a combination of transcription and semantic translation. Some characterising names are not semantically translated, for instance, Mr Porkenham (pork and ham) - пан Поркенгем in Pickwick Papers by Charles Dickens. Semantic translation of surnames and first and middle names is not practiced.

The method of the functional analogue is primarily used for phraseological units and proverbs. The functional analogue can cause perception in Ukrainian text similar to English text. For instance, "Jack of all trades" can be conveyed in Ukrainian as " $\mathrm{Ha}$ в руки майстер" where Jack is not translated at all.

The method of transliteration conveys English proper names in Ukrainian: Barbara - Барбара, Norman - Норман, Wilson Вільсон. This method prevailed in XVIII-XX centuries. The exactitude of rendering using transliteration is based on the writing of English letters by means of the Ukrainian graphics, partially ignoring an audible image of a name. The main rules of the transliteration of English are provided in subsection 4.1 of the Recommendations of the former State Service of Intellectual Property in Ukraine [2].

Some English proper names of people are transliterated with the omission or addition of a letter or two in Ukrainian to avoid the violation of the traditional spelling in Ukranian: McDonald - МакДональд, McEnroe - МакЕнро, Dinah - Діна, Longfellow Лонгфелло, Williamson - Вільямсон.

The method of transcription reflects the principle of phonetic similarity. Researchers emphasize a tendency of recent decades to transcribe foreign proper names. The aim of transcription is to convey English phonemes by Ukrainian graphics. There are some rules to render English phonemes into Ukrainian. The diagraph ia [Іә] at the end of names is conveyed in Ukrainian as $\sim і я:$ Cecilia Сесілія, Lucia - Лусія. The ending ian [ıә] is conveyed as іан: Christian - Крістіан, Dorian - Доріан.

The most common Ukrainian substitutes for English short vowels-monophthongs are as follows [4;5]:

\begin{tabular}{|c|c|c|}
\hline English graphics & Ukrainian graphics & Example \\
\hline $\mathrm{a}$ & $\mathrm{a}, \mathrm{e}$ & $\begin{array}{l}\text { Angela-Анджела/Енджела, } \\
\text { Andy - Андi/Ендi }\end{array}$ \\
\hline $\mathrm{u}$ & $\mathrm{a}, \mathrm{y}, \mathrm{o}$ & \begin{tabular}{|l|} 
Ulrica - Алріка/ Ульріка, \\
Ulster-Ольстер \\
\end{tabular} \\
\hline o & o & Dolly - Доллі, Oscar - Оскар \\
\hline $\mathrm{i}$ & $\mathrm{i}$ & Isabel - Ізабел( $а$ ), Isolda - Ізольда \\
\hline \multirow[t]{2}{*}{$\mathrm{e}$} & $\mathrm{e}$ & Eckersly - Екерслі, Ellis - Елліс \\
\hline & $\mathrm{i}$ & Ede $-I \partial$, Eden $-I \partial е н$ \\
\hline
\end{tabular}

English long vowel phonemes are substituted with Ukrainian vowels that are short phonemes:

\begin{tabular}{|c|c|c|}
\hline English phoneme & Ukrainian graphics & Example \\
\hline [a:] & $\mathrm{a}$ & Bart - Барт, Clerke - Кларк \\
\hline$[0:]$ & o & Allcorn - Олкорн, Austin - Остін \\
\hline [u:] & $\mathrm{y}$ & Cooper - Kуnер, Rubens - Рубенс \\
\hline [ju:] & ю & Newton - Ньютон \\
\hline [i:] & $\mathrm{i}$ & Celia-Сілія \\
\hline [ə:] & $\mathrm{e}, \mathrm{i}$ & $\begin{array}{l}\text { Herbert - Герберт, } \\
\text { Irving - Ервін/ Ірвін }\end{array}$ \\
\hline
\end{tabular}

English vowel-diphthongs are substituted with a Ukrainian letter or letter combinations:

\begin{tabular}{|c|c|c|}
\hline English phoneme & Ukrainian graphics & Example \\
\hline [aI] & ай & Mike - Maйк, Isaac-Айзак \\
\hline [au] & ay & Howard - Гayapd, Lowry - Лayapi \\
\hline$[\mathrm{eI}]$ & ей & Mabel - Мейбл, James - Джеймз \\
\hline [эI] & ой & Croydon - Кройдон, Rоy - Рой \\
\hline [əu] & oy & $\begin{array}{l}\text { Mowgli - Моуглі, Owen - Оуен } \\
\text { but Bruno ['bru:nəu] - Бруно, Longfellow ['loyfeləu] - Лонгфелло, Poe [pәu] - По }\end{array}$ \\
\hline [eə] & $\mathrm{e}$ & Fairfax - Ферфакс, Fairbanks - Фербанкс \\
\hline [Ia] & ія & Victoria-Вікторія, Virginia-Вірджинія \\
\hline
\end{tabular}

Ukrainian substitutes for some English consonant phonemes are as follows:

[y] - нг: Long - Лонг

[yk] - нк: Bronx - Бронкс, Sinclair - Сінклер

$[\mathrm{k}]-\kappa$ : Cooper - Kynep

$[\mathrm{g}]-\tau$ : Gregory - Ipétopi

$[\mathrm{z}]-3$ : Zaharias - 3axapiac

$[\mathrm{r}]-p$ : Richard -Piчард

[h] - 2: Harry - Гappi.

Some English phonemes can be rendered into Ukrainian by means of approximate graphical substitutes rather than direct equivalents. This method is called practical transcription that combines transcription and transliteration to identify a person, for 
instance, George - Джордж, where ' $\mathrm{r}$ ' is not pronounced but transliterated. It facilitates the restoration of the original name of a person $[3$, c. 20].

The method of transposition is used when people's proper names have common etymology but different forms in the source and target languages. In this case, the equivalent is used to convey a name from English into Ukranian: St Michael - святий Михаїл, St Nicholas - святий Миколай. Some researchers believe that this method contradicts the national and language specifics of common names: Nicholas is Ніколас in Ukrainian, Charles is Чарльз rather than Карл. We do not use the method of transposition with common names though Biblical, religious and historical names are rendered into Ukranian by means of the transposition method, i. e. a traditional name is used, for instance, King James is rendered as король Яков, Charlemagne - Карл Великий, Prince Charles прини Карл.

The tradition-based method is mainly used to render Biblical, religious and historical names of people. Traditional forms of names are culture-loaded. So, 'George' has three equivalents in Ukrainian: George Bush - Джордж Буш, King George - король Георг, St George - святий Георгій. 'Adam' can be conveyed as Адам (Biblical) or Eдам (common name), 'David' - Давід (Biblical) or Дейвід (common name), 'Matthew' - Матфей/ Mатвій (Biblical) or Метью (common name), 'Pope John Paul II' - Папа Іван Павло Другий. The names of kings, queens, princes, princesses, tsars, tsarinas are conveyed traditionally, for instance, 'Queen Elisabeth' королева Слизавета, 'Mary Stewart' - Марія Стюарт, 'Princess Ann' - принцеса Анна. Therefore, traditional orthographic forms in Ukrainian do not completely reflect the pronunciation of names or their orthographic forms in English.

The method of tracing (калькування) is primarily used for toponyms: White House - Білий Дім. The method of half-tracing (напівкалькування) is a combination of semantic translation and transcription or transliteration: King Thorne - король Торн.

The method of euphonic rendering is used to bypass strange associations, pronunciation or spelling in Ukranian, for instance, the surname Шитіков is conveyed as Chitikov. The method of explication is used to specify a person's proper name in terms of gender, sex, position etc., for instance, Johnson - прем'єр-міністр Дюсонсон, Horatio Nelson - адмірал Гораціо Нельсон.

The method of mixed rendering provides a combination of semantic translation and transcription or transliteration: 'Pope Paul' Папа Павло. The method of the rendering of people's proper names without changes, when the names are written in Latin, is used in the media though it is not recommended because some people do not read in Latin, for instance, the word Internet should be presented as Інтернет. The method of transplantation means that the name of non-English origin in Latin can stay unchanged, for example, Angelica.

There are some features in rendering people's proper names. The shortened forms of names are as follows: Dick - Richard, Bill - William, Jack - John, Ab - Abraham. In English, the names Sasha, Natasha, Tania etc. can be full names. The names Misha and Mischa in English can be the names of females.

The stress of words in the target language can differ from the language of origin: in 'Dennis' the stress falls on the first syllable whereas in Денис the stress is on the second syllable.

Sometimes it is impossible to get transcription of names in dictionaries. In this case, we can use an analogy between the word under scrutiny and well elaborated words, for instance, we can transcribe the surname Shaw as [Jo:], using sh [J] and -aw [0:] by analogy with claw, draw, paw, straw etc. So, in Ukrainian the surname Shaw will be Шo.

According to D. Ermolovich, recommendations to render people's proper names into a foreign language are as follows:

1) to make sure that it is a proper name;

2) to determine what class of objects is named - a human being, a company etc.;

3) to identify what nation and what language a proper name belongs to as an original language influences pronunciation and transcription of names;

4) to find out traditional equivalents of a name;

5) to make a decision how to translate a word taking into account the form and content of a proper name as well as target reader [3, c. 32-35].

An official web-portal of the former State Service of Intellectual Property of Ukraine [2] contains the Recommendations that include the rules to write an English proper name using the Ukrainian alphabet:

1 - to write the transcription of a proper name, using a dictionary and appendices A and B $(\boldsymbol{b})$ of the Recommendations;

2 - to present each transcription sign or a sign combination using a Ukrainian letter or a letter combination (table 1 of the Recommendations);

3 - to correct the rendering of long vowels: if a vowel is long because it is followed by the English letter " $r$ ", the Ukrainian letter " $p$ " is used in a Ukrainian word (work [wə:k] - өорк);

4 - to use the Ukrainian letter " $p$ " to render the English $\sim \mathrm{r}$ and $\sim$ re at the end of a word (fire [ farə] - фaйp);

5 - to harmonize a text with the standards of Ukrainian orthography.

Thus, personal names have six main functions: identification, reference, individualisation, differentiation, classification and categorisation. Personal names can signal a multitude of things - gender, race, social class, age, nationality and demographics. The strategies to render English anthroponyms into Ukrainian are based on the methods, the meaning of names, their image and function, the national and language specifics of names, a pragmatic task and the use of a dictionary of English personal names. The methods of rendering proper names are semantic translation, functional analogue, transliteration, transcription, transposition, tradition, tracing, half-tracing, euphonic rendering, explication, combined rendering, rendering a name in Latin and transplantation. Choosing a correct strategy to convey names and surnames from English into Ukrainian provides us with the capability to render names properly.

The perspective of research focuses on the investigation of the cognitive properties of people's proper names.

\section{Literature:}

1. Алексахин А. Н. Алфавит китайского языка путунхуа. Буква. Фонема. Звук. Слог : для начинающих и продолжающих изучать китайский язык. М.: АСТ: Восток-Запад; Владимир: ВКТ, 2008. 96 с.

2. Державна служба інтелектуальної власності МОНУ. URL: http://web.archive.org (дата звернення 26.08.2021).

3. Ермолович Д. И. Имена собственные на стыке языков и культур. М., 2001. 200 с.

4. Карабан Вячеслав. Переклад англійської наукової і технічної літератури. Вінниця: Нова Книга, 2004. 576 с. 
5. Корунець I. В. Теорія і практика перекладу (аспектний переклад) : підручник. Вінниця: Нова Книга, 2001. 448 с.

6. Alford R. D. Naming and Identity: A Cross-cultural Study of Personal Naming Practices. New Haven, CT: HRAF Press, 1988.190 p.

7. Brennen Tim. On the Meaning of Personal Names: A View from Cognitive Psychology. Names 48.2. 2000. P. 139-146.

8. Brewer Marilynn B., Layton N. Lui. The Primacy of Age and Sex in the Structure of Person Categories. Social Cognition 7(3). 1989.

P. 262-274. URL: https://doi.org/10.1521/soco. 1989.7.3.262 (дата звернення 26.08.2021).

9. Cohen Gillian. Why is it difficult to put names to faces? British Journal of Psychology 81. 1990. P. $287-297$.

10. Dorian N. C. A substitute name system in Scottish Highlands. American Anthropologist, 72. 1970. P. 303-319.

11. Garcia-Ramirez E. Proper Names. A Cognitive-Philosophical Study : Dissertation for the degree of Doctor of Philosophy, University of Michigan, 2010. $168 \mathrm{p}$.

12. Goodenough W. H. Personal names and modes of address in two Oceanic societies. Context and Meaning in Cultural Anthropology. New York: Free Press. 1965. P. 265-276.

13. Günter Vittmann. Encyclopaedia of Egyptology. Personal Names. Function and Significance. 2013. URL: https://escholarship.org/ uc/item/7t12z11t (дата звернення 26.08.2021).

14. Johfre Sasha Shen. What Age Is in a Name? Sociological Science 7. 2020. P. 367-390.

15. Kasof Joseph. Sex Bias in the Naming of Stimulus Persons. Psychological Bulletin 113. 1993. P. 140-163.

16. Lawson Edwin D., Lynn M. Roeder. Women's Full First Names, Short Names, and Affectionate Names: a Semantic Differential Analysis. Names 34. 1986. P. 175-84.

17. McWeeny Kathryn, Andy Young, Dennis Hay, Andy Ellis. Putting names to faces. British Journal of Psychology 78. 1987. P. 143-49.

18. Mehrabian Albert. Impressions Created by Given Names. Names 45. 1997. P. 19-33.

19. Oxford Advanced Learner's Dictionary. New $9^{\text {th }}$ Edition. 2015. 1820 p.

20. Tim Valentine, Tim Brennen, Serge Bredart. The Cognitive Psychology of Proper Names. 1996. 226 p. 